\title{
Microorganisms Isolated from Sawmill and Poultry Farm and their Long Term Health Effects in Human Health
}

\author{
B.S. Baranu* and E. Edmund \\ Department of Microbiology, Rivers State, University of Science and Technology, P.M.B \\ 5080, Port Harcourt, Nigeria \\ *Corresponding author
}

\begin{tabular}{|l}
\hline K e y w o r d s \\
$\begin{array}{l}\text { Sawmill and } \\
\text { Poultry farm, } \\
\text { Microorganisms }\end{array}$ \\
\hline Article Info \\
\hline $\begin{array}{l}\text { Accepted: } \\
\text { 07 February } 2019 \\
\text { Available Online: } \\
\text { 10 March } 2019\end{array}$ \\
\hline
\end{tabular}

\section{A B S T R A C T}

Microorganisms from dusts of organic origin was identified from some saw mill, (Site 1) and a poultry farm (Site 1) in Port Harcourt. The exposure to these organic dusts by people employed in these establishments over a long period of time can lead to occupational health diseases especially in immune compromised persons. Nutrient Agar, Sabaroud Dextrose Agar (SDA), and Mac Conkey Agar (MA) in sedimentation method were used to isolate microorganisms. In Sample Site1, the Total Heterotrophic Bacteria (THB) was greater than the Total Enteric Bacteria (TEB) and the Total Aerobic Fungi (TAF) on a dry day while the THB is greater than TAF $>$ TEB on a wet season. While in station 2, THB $>$ TEB > TAF during the dry season and THB > TEB > TAF during the wet season. This result revealed that heterotrophic bacteria are the most dominant during the rainy and dry season in both sites. Between the two sites, microbial concentration in Site 2 (poultry farm) at $2.115 \mathrm{cfu} / 10 \mathrm{~min} / \mathrm{m}^{2}$ is greater than Station 1 (sawmill) at $1.608 \mathrm{cfu} / 10 \mathrm{~min} / \mathrm{m}^{2}$ ), this might be due to the fact that it is a confined area in which birds are bred and its system of ventilation is poor. These microorganisms identified in various concentrations can cause pulmonary dysfunctions and allergic diseases such as Aspergillosis, Hypersensitivity pneumonitis, chronic bronchitis, rhinitis etc. There is therefore need for workers in these organic dust prone areas to make use of the most practical respirators (nose masks) with the highest assigned protection factor (APF).

\section{Introduction}

The risks associated with prolonged exposure to grain dusts were first identified in the early $16^{\text {th }}$ century and its exposure has been a major source of mortality among agricultural workers (Schenker, 2000). Dusts can be referred to as very fine solid particles that are usually suspended in the air and they result from the breakdown of materials in order to propel fine fragments into a gaseous medium (Laakkonen, 2008). Dusts can have different sizes (ranging from 1-100 $\mu \mathrm{m}$ ) and they tend to settle out under gravitational influence (ISO, 1995). Their effects on the human body are to a large extent dependent on their respective sizes and nature, also these factors determine their site of deposition within the respiratory system (Laakkonen, 2008). The dusts are usually either larger sized or smaller 
sized, dusts of larger sized particles are referred to as inhalable dusts and most of them are filtered out into the nose, throat and upper respiratory tract (TUC 2011; Laakonen, 2008). Whereas, smaller sized particles when inhaled can go as far as the alveoli and the lungs and they are referred to as respirable dusts, these smaller particles when incessantly inhaled over a long period of time can pose a threat to human health (TUC, 2011).

Based on their sources, dusts can be categorized into two types which are Organic dusts and inorganic dusts (Schenker, 2000).

The word "organic dust" also refers to "bioaerosols" and it is defined as fine particles of biological origin (microbial, plant or animal) that are suspended in the air (Douwess et al., 2003). These particles are usually impregnated with microorganisms and they include include dusts from wood, flour, cotton fibres, paper fibres, fur from animals, hay, grains, animal scales, animal dander, evaporated urine droplets and fecal, household wastes etc (Eduard and Halstensen, 2009). Organic dusts are usually launched into the air by natural forces, such as wind, volcanic eruption, and by mechanical or anthropogenic processes such as crushing, grinding, milling, drilling, demolition, conveying, screening, bagging, and sweeping (ISO, 1995).

Organic dusts occur in a range of occupations including agricultural work; the textile industry, especially cotton processing; flour milling and bakeries; and the wood industry, particularly sawmills, carpentry, and wood processing, the waste management industry and so many others. Many of these occupations, particularly agricultural work, also have the highest potential for concurrent exposure to other substances that affect respiratory health, for example metals, gases, fibres, and chemicals (Omland, 2002).
These bioaerosols are active and they are made up of some components that result in adverse health effects to exposed workers due to prolonged exposure, Some of these agents are bacterial endotoxins, fungi, viruses, high molecular weight allergens, mycotoxins, pollens, moulds, proteins from animal hair, urine and droppings, and enzymes which act as allergens, tannins, plicatic acid etc (Douwess et al., 2003).

\section{Materials and Methods}

\section{Study area and sample collection}

The study was carried out in two sampling sites, one is the Sawmill located at Timber street by Iloabuchi mile 1, Port-Harcourt (Latitude 4.7893765, N 4047'19.38876' ' and Longitude 6.9831649, E6 ${ }^{0} 59$ '18.62376' '), and the poultry farm located within Rivers State University, Nkpolu-Oroworukwo, PortHarcourt (Latitude $4.80234 \quad \mathrm{~N}^{\circ} 48^{\prime} 8.4096$ Longitude 6.97713 E 6 58 '37.68096')' The Sawmill is a facility where logs of wood are cut into lumber, here wood and wood products are processed, the facility comprises mainly of male workers and the activities that take place in the sawmill involves the transportation of fresh logs of wood from the forest, sawing of the wood, packaging of the lumber, transportation and the export of the cut lumbers.

The Nutrient Agar (NA), Mac Conkey Agar (MA) and Sabouraud Dextrose Agar (SDA) plates were exposed to the organic dusts in sites 1 and 2 for about 10 minutes and the isolates were collected from each source during the wet day and dry day.

The bacterial and fungal isolates were determined using Koch's sedimentation method (settle plate technique). In this technique, microorganisms from the organic dusts get settled directly on the prepared agar 
plates exposed on a $4 \mathrm{ft}$ high wooden stool for a period of 10 minutes. The exposed Nutrient agar and Mac-conkey agar were incubated at $37^{\circ} \mathrm{c}$ for 24 hours while the Sabouraud dextrose agar plates were incubated at room temperature for 72 hours. The colonies that were formed on the culture plates were recorded as colony forming units per 10 minutes and expressed as cfu/ $10 \mathrm{mins} / \mathrm{m}^{2}$ of air using the following formula:

$\mathrm{Cfu} / 10 \mathrm{~min} / \mathrm{m}^{2}=$ No. of colonies $\times 10 \times 3.142 \mathrm{r}^{2}$ Time of exposure

Where,

$r=$ radius of media plate used (in meters)

\section{Isolation of pure cultures}

Discrete colonies were all sub-cultured to obtain pure colonies. This was achieved by streaking a loop-full of a particular isolate on an already prepared Nutrient agar plate and incubated at $37^{\circ} \mathrm{c}$ for another 24 hours. The pure cultures were stored accordingly in a nutrient agar slant for further studies.

\section{Characterization of bacterial isolates}

This characterization was done firstly by morphological identification of respective colonies, this was followed by using conventional methods which include Gram staining, biochemical tests such as catalase, coagulase, oxidase, urease, motility, methylred(MR), Vogues Proskauer (VP), sugar fermentation tests which include mannitol, glucose, maltose, lactose and starch hydrolysis.

Identification was based on comparison of the characteristics of the isolates with those of the taxa. Details of the test procedures are as follows.

\section{Characterization of fungal isolates}

The identification of fungal isolates was carried out using standard methods based on macroscopic and microscopic features as described by Ellis (1971), Domsch et al., (1980). In macroscopic identification, the aerial and substratum regions were observed for colour, colony structure, colony number and nature of growth. In microscopic examination, two drops of cotton blue in lacto-phenol is stained in the center of a clean grease-free slide. A small portion of the fungus was picked from the sub-cultured plate using a sterilized inoculating needle and it was placed on the slide and covered with a cover slip. It was examined under the microscope at low power and high power (x10 and $\mathrm{x} 40$ respectively).

\section{Results and Discussion}

The following fungal features were noted in this test:

Somatic structure

Vegetative structure

Reproductive structure

Conidial head and vesicle shapes

Surface appearance

Colony colour

In station 1, total Heterotrophic Bacteria (THB) $0.804>$ Total Enteric Bacteria (TEB) 0.576> Total Aerobic Fungi (TAF) 0.108 during dry day and TEB $0.204>$ THB $0.144>$ TAF 0.060 during the wet day. While in station 2, THB $0.846>$ TEB $0.732>$ TAF 0.192 during the dry day and THB 0.132> TEB $0.114>$ TAF 0.066 during the wet day (Fig. 1-6 and Table 1-6). This result reveals that in both stations, heterotrophic bacteria are the most dominant during the rainy and dry season It also reveals that the concentration of microorganisms decreased in the wet day than during the dry season in both stations and this 
result correlates with that of (Achudume et al., 2009) which states that dusts and microbial proliferation are much higher in dry seasons than in wet seasons. In station 1, THB are of 12 species which include Paenibacillus lautus, Bacillus badius, Bacillus carboniphilus, Staphylococcus saccharolyticus, Brevibacillus laterosporus, Staphylococcus aureus, Lactobacillus kitasatonis, Macrococcus brunensis, Bacillus smithii, Staphylococcus massiliensis, and Streptococcus parasuis with staphylococcus species forming about $40.4 \%$ of the total heterotrophic bacteria. The TEB include Bacillus badius, Erwiniaspp, Shigelladysenteriae, Escherichia coli, Klebsiella pneumonia, Lactobacillus kitasatonis Corynebacteriumafermentans with, Klebsiella pneumonia being the most dominant forming $26.67 \%$ of the total enteric bacteria. The TAF include Apergillus Flavus, MucorSpp, Rhizopus stolonifer, Aspergillus Niger, Aspergillus Fumigatus, Rhizopus arrhizus, and Epicoccum nigrum with Aspergillus Niger being the most dominant with about $21.97 \%$ of the total aerobic fungi.

Whereas in station 2, the THB are of 9 species which include Staphylococcus saccharolyticus, Pseudomonas spp, Bacillus badius, Staphylococcus aureus, Lactobacillus kitasatonis, Macrococcus brunensis, Bacillus smithii, Streptococcus parasuis, and Staphylococcus massiliensis out of which Staphylococcus aureus was the most dominant constituting $34.66 \%$ of the total heterotrophic bacteria. Seven (7) species of enteric bacteria were identified and they include Serratia species, Escherichia coli, Enterococcus faecalis, Klebsiella pneumoniae, Proteus mirabilis, Enterobacter cloacae and Hafnia alvei out of which Escherichia coli dominated most constituting $25.42 \%$ of TEB. Eight (8) species of aerobic fungi were identified and they include Apergillus flavus, Mucor spp, Aspergillus niger, Aspergillus fumigatus, Rhizopus arrhizus, Epicoccum nigrum, Saccharomyces spp, Penicillium spp with Apergillus flavus being the most dominant constituting about $24.47 \%$ of the total aerobic fungi. Between the two stations, microbial concentration in station 2 (poultry farm) $2.115 \mathrm{cfu} / 10 \mathrm{~min} / \mathrm{m}^{2}$ $>$ station 1 (sawmill) $1.608 \mathrm{cfu} / 10 \mathrm{~min} / \mathrm{m}^{2}$ ), this might be due to the fact that it is a confined area in which birds are bred and its system of ventilation is poor. Bacterial and fungal concentration in organic dust and their harmful effect on human health depends on different environmental factors including source materials, climatic condition and the level of ventilation in the place of study (Dutkiewicz et al., 2000).

Among the microorganisms occurring in organic dust three (3) groups were identified from the major groups that could be identified. These groups include gramnegative bacteria (producing endotoxin, which are mostly epiphytic species developing abundantly on plant surfaces as saprobionts), gram-positive bacteria (which are predominant organisms in dusts of animal origin and may be also very common in dusts from stored plant materials) and fungi (comprising multicellular filamentous fungi described as moulds and unicellular yeasts, are common in organic dusts). These microorganisms may penetrate into deeper parts of the lungs causing undesirable harmful effects on human health. Bacteria and fungi occurring in organic dusts are mainly noninfectious but may however exert adverse effects on respiratory tract of exposed persons causing mucous membrane irritation (MMI), immunotoxic diseases such as organic dust toxic syndrome (ODTS), inhalation fever, grain fever, toxic pneumonitis, byssinosis, humidifier syndrome, mycotoxicoses and allergic diseases such as allergic alveolitis (hypersensitivity pneumonitis) chronic bronchitis, granulomatous pneumonitis, 
asthma and allergic rhinitis. Though over 180 Aspergillus spp are known, only four are associated with invasive infections in humans, these species include Aspergillus niger, Aspergillus fumigatus, Aspergillus flavus and Aspergillus terrus out of which the first three were isolated. These species cause chronic infections especially in immune-compromised individuals, the infections include fungus ball
(Aspergilloma) allergic broncho-pulmonary aspergillosis (ABPA), chronic pulmonary aspergillosis (CPA) Invasive pulmonary aspergillosis (IPA). (Jorge, 2004).Gram negative bacteria such as E.coli as well as other pathogenic microbes which include Yersinia sp and Pseudomonas sp release endotoxins which cause byssinosis.

Table.1 Frequency of occurrence and CFU|10mins of fungal isolates from sample site 1 (Saw Mill)

\begin{tabular}{|l|c|c|c|c|}
\hline \multicolumn{1}{|c|}{ Organisms } & \multicolumn{2}{|c|}{ Dry Day } & \multicolumn{2}{c|}{ Rainy Day } \\
\hline Apergillus flavus & Mean Frequency & $\begin{array}{c}\text { CFU/10mins } \\
\mathbf{/ m}^{\mathbf{2}}\end{array}$ & $\begin{array}{c}\text { Mean } \\
\text { Frequency }\end{array}$ & $\begin{array}{c}\text { CFU/10min } \\
\mathbf{/ m}^{\mathbf{2}}\end{array}$ \\
\hline Mucor spp & 3 & 0.018 & 1 & 0.006 \\
\hline Rhizopus stolonifer & 2 & 0.012 & 1 & 0.006 \\
\hline Aspergillus niger & 2 & 0.012 & 1 & 0.006 \\
\hline Aspergillus fumigatus & 2 & 0.024 & 1 & 0.006 \\
\hline Rhizopus arrhizus & 2 & 0.012 & 3 & 0.018 \\
\hline Epicoccum nigrum & 3 & 0.012 & 1 & 0.006 \\
\hline
\end{tabular}

Table.2 Frequency count and CFU of Total Heterotrophic Bacteria from Saw mill

\begin{tabular}{|l|c|c|c|c|}
\hline Organisms & \multicolumn{2}{|c|}{ Dry Day } & \multicolumn{2}{c|}{ Rainy Day } \\
\hline & $\begin{array}{c}\text { Mean } \\
\text { frequency }\end{array}$ & $\begin{array}{c}\text { CFU/10mins } \\
\mathbf{/ m}^{\mathbf{2}}\end{array}$ & $\begin{array}{c}\text { Mean } \\
\text { frequency }\end{array}$ & $\begin{array}{c}\text { CFU/10mins } \\
/ \mathbf{m}^{\mathbf{2}}\end{array}$ \\
\hline Paenibacillus lautus & 11 & 0.066 & 1 & 0.006 \\
\hline Bacillus badius & 17 & 0.102 & 2 & 0.012 \\
\hline Bacillus carboniphilus & 12 & 0.072 & 1 & 0.006 \\
\hline S. saccharolyticus & 12 & 0.072 & 2 & 0.012 \\
\hline Brevibacillus laterosporus & 10 & 0.060 & 2 & 0.012 \\
\hline Staphylococcus aureus & 26 & 0.156 & 1 & 0.006 \\
\hline Lactobacillus kitasatonis & 7 & 0.042 & 4 & 0.024 \\
\hline Macrococcus brunensis & 4 & 0.024 & 3 & 0.018 \\
\hline Bacillus smithii & 12 & 0.072 & 6 & 0.036 \\
\hline Staphylococcus massiliensis & 13 & 0.078 & 0 & 0 \\
\hline Streptococcus parasuis & 10 & 0.060 & 2 & 0.012 \\
\hline
\end{tabular}


Table.3 CFU and frequency for enteric bacteria from sample site 1(saw mill)

\begin{tabular}{|l|c|c|c|c|}
\hline \multirow{2}{*}{ Organisms } & \multicolumn{2}{|c|}{ Dry day } & \multicolumn{2}{c|}{ Rainy Day } \\
\cline { 2 - 5 } & Frequency & $\begin{array}{c}\text { CFU/10mins } \\
\text { / }^{\mathbf{2}}\end{array}$ & Frequency & CFU/10min $/ \mathbf{m}^{\mathbf{2}}$ \\
\hline Bacillus smithii & 8 & 0.048 & 3 & 0.018 \\
\hline Bacillus badius & 15 & 0.09 & 7 & 0.042 \\
\hline Erwinia spp & 18 & 0.108 & 4 & 0.024 \\
\hline Shigella dysenteriae & 12 & 0.072 & 5 & 0.030 \\
\hline Escherichia coli & 8 & 0.048 & 4 & 0.024 \\
\hline K. pneumoniae & 23 & 0.138 & 3 & 0.018 \\
\hline L. kitasatonis & 4 & 0.024 & 4 & 0.024 \\
\hline Corynebacterium afermentans & 8 & 0.048 & 4 & 0.024 \\
\hline
\end{tabular}

Table.4 Frequency count and CFU of aerobic fungi isolated from sample site 2 (RSU poultry farm

\begin{tabular}{|l|c|c|c|c|}
\hline \multirow{2}{*}{ Organisms } & \multicolumn{2}{|c|}{ Dry day } & \multicolumn{2}{c|}{ Rainy day } \\
\cline { 2 - 5 } & $\begin{array}{c}\text { Mean } \\
\text { frequency }\end{array}$ & CFU/10mins/m² & $\begin{array}{c}\text { Mean } \\
\text { frequency }\end{array}$ & $\begin{array}{c}\text { CFU/10mins/m } \\
\mathbf{2}\end{array}$ \\
\hline Apergillus flavus & 4 & 0.024 & 1 & 0.006 \\
\hline Aspergillus fumigatus & 3 & 0.018 & 0 & 0 \\
\hline Rhizopus arrhizus & 4 & 0.024 & 1 & 0.006 \\
\hline Epicoccum nigrum & 3 & 0.018 & 2 & 0.012 \\
\hline Saccharomyces spp & 3 & 0.018 & 0 & 0 \\
\hline Penicillium spp & 7 & 0.042 & 3 & 0.018 \\
\hline
\end{tabular}

Table.5 Frequency count for Heterotrophic Bacteria from sample site 2 (RSU poultry farm)

\begin{tabular}{|l|c|c|c|c|}
\hline \multirow{2}{*}{ Organisms } & \multicolumn{2}{|c|}{ Dry Day } & \multicolumn{2}{c|}{ Rainy Day } \\
\cline { 2 - 5 } & $\begin{array}{c}\text { Mean } \\
\text { frequency }\end{array}$ & $\begin{array}{c}\text { CFU/10mins } \\
/ \mathbf{m}^{\mathbf{2}}\end{array}$ & $\begin{array}{c}\text { Mean } \\
\text { frequency }\end{array}$ & $\begin{array}{c}\text { CFU/10mins } \\
\text { /. }\end{array}$ \\
\hline Pseudomonas spp & 4 & 0.024 & 5 & 0.030 \\
\hline Bacillus badius & 5 & 0.030 & 0 & 0 \\
\hline S. saccharolyticus & 13 & 0.078 & 5 & 0.030 \\
\hline Staphylococcus aureus & 48 & 0.288 & 3 & 0.018 \\
\hline Lactobacillus kitasatonis & 12 & 0.072 & 2 & 0.012 \\
\hline Macrococcus brunensis & 9 & 0.054 & 1 & 0.006 \\
\hline Bacillus smithii & 20 & 0.120 & 2 & 0.012 \\
\hline Staphylococcus massiliensis & 15 & 0.090 & 1 & 0.006 \\
\hline Streptococcus parasuis & 15 & 0.090 & 3 & 0.018 \\
\hline
\end{tabular}


Table.6 Mean frequency and CFU of Enteric Bacteria from sample site 2 (RSU poultry farm)

\begin{tabular}{|l|c|c|c|c|}
\hline \multirow{2}{*}{ Organisms } & \multicolumn{2}{|c|}{ Dry Day } & \multicolumn{2}{c|}{ Rainy Day } \\
\cline { 2 - 5 } & $\begin{array}{c}\text { Mean } \\
\text { frequency }\end{array}$ & CFU/10mins/m² & $\begin{array}{c}\text { Mean } \\
\text { frequency }\end{array}$ & CFU/10mins/m \\
\hline Escherichia coli & 31 & 0.186 & 3 & 0.018 \\
\hline Serratia marcescens & 4 & 0.024 & 5 & 0.030 \\
\hline Enterococcus faecalis & 5 & 0.030 & 0 & 0 \\
\hline Klebsiella pneumoniae & 13 & 0.078 & 5 & 0.030 \\
\hline Proteus mirabilis & 48 & 0.288 & 3 & 0.018 \\
\hline Enterobacter cloacae & 12 & 0.072 & 2 & 0.012 \\
\hline Hafnia alvei & 9 & 0.054 & 1 & 0.006 \\
\hline
\end{tabular}

Fig.1 Percentage frequency of occurrence of fungal isolates from sample site 1 (Saw Mill)

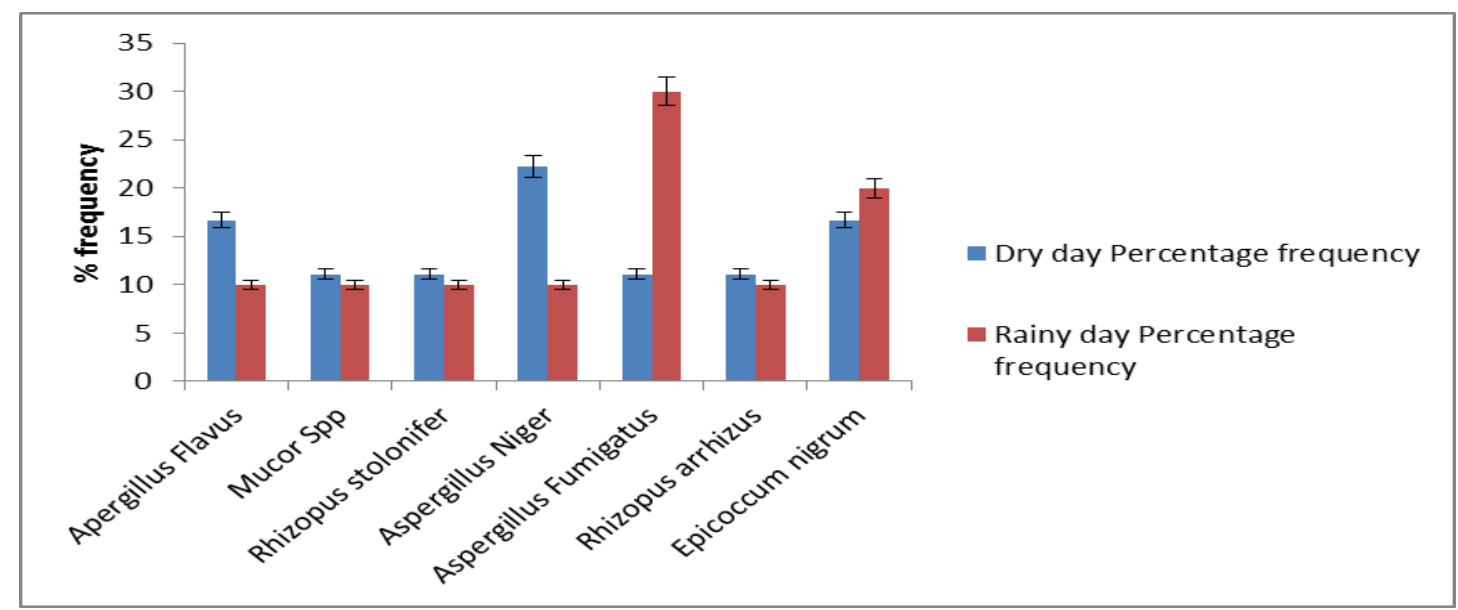

Fig.2 Chart showing percentage frequency of heterotrophic bacteria isolates from sample site 1 (saw mill)

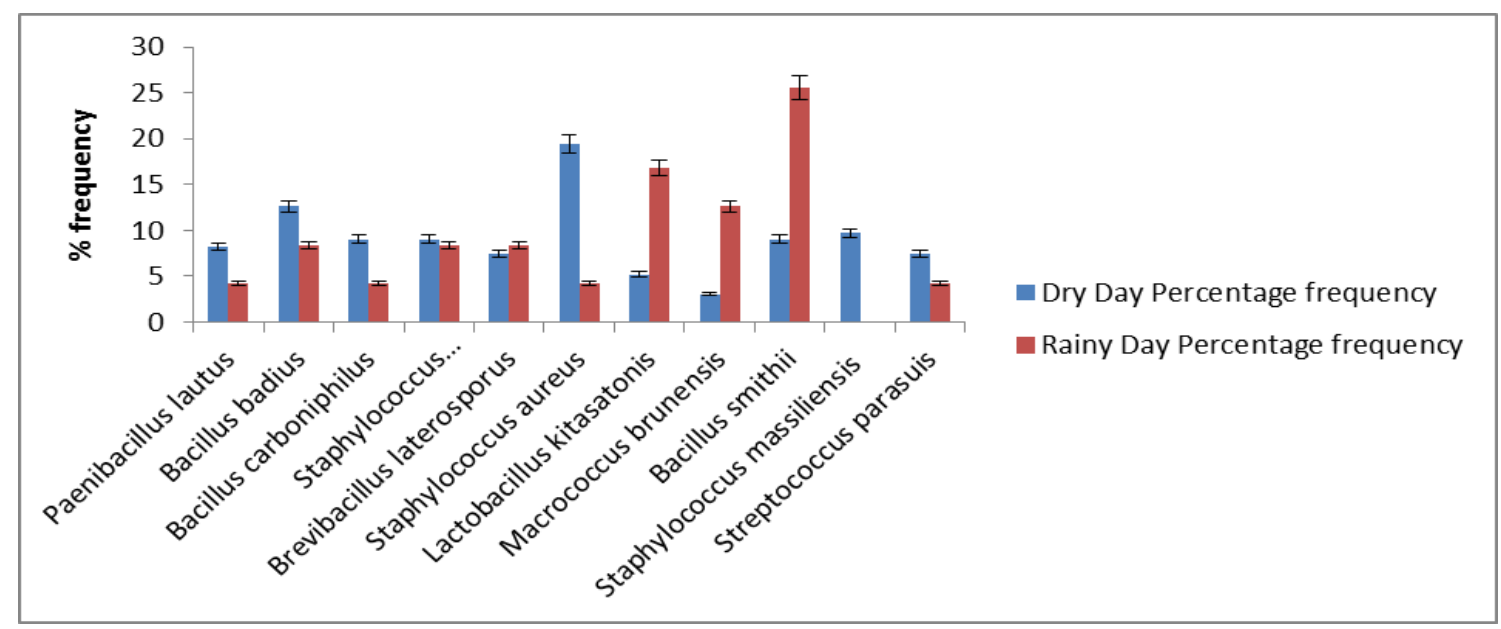


Fig.3 Percentage frequency of enteric bacteria isolates from saw mill

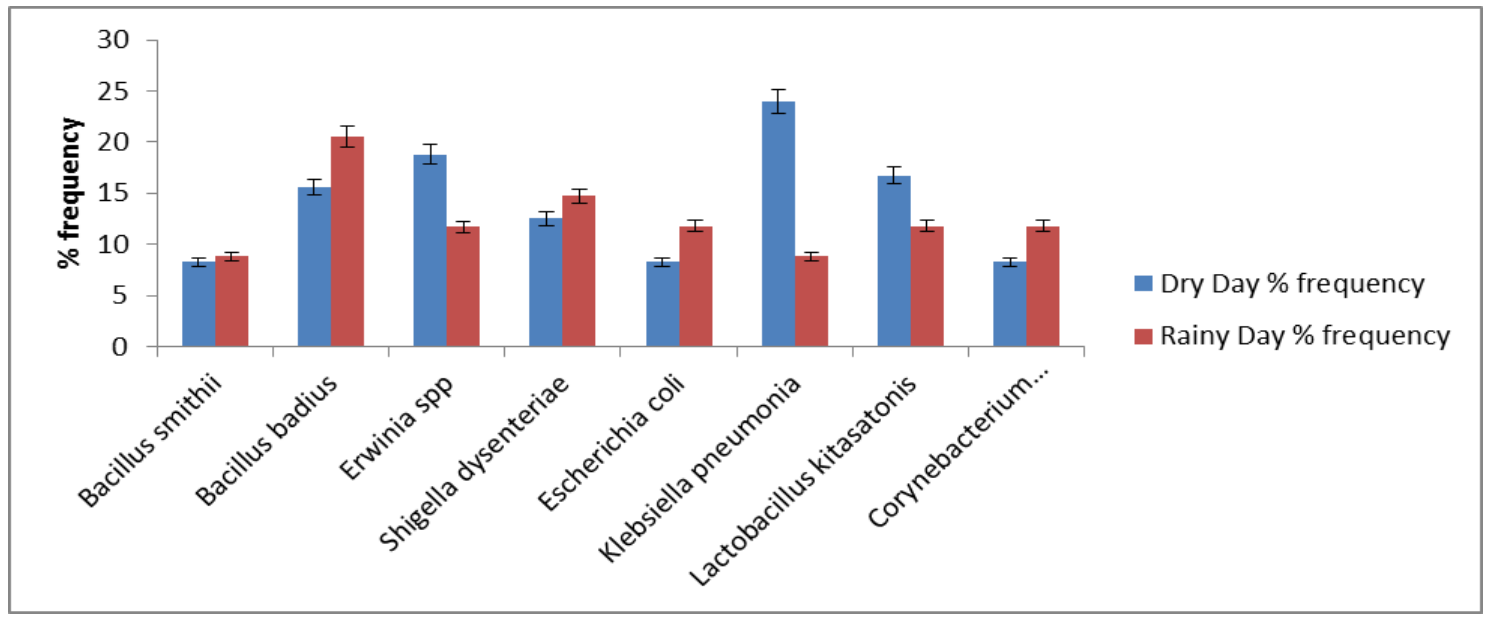

Fig.4 Percentage frequency of aerobic fungi from sample site 2

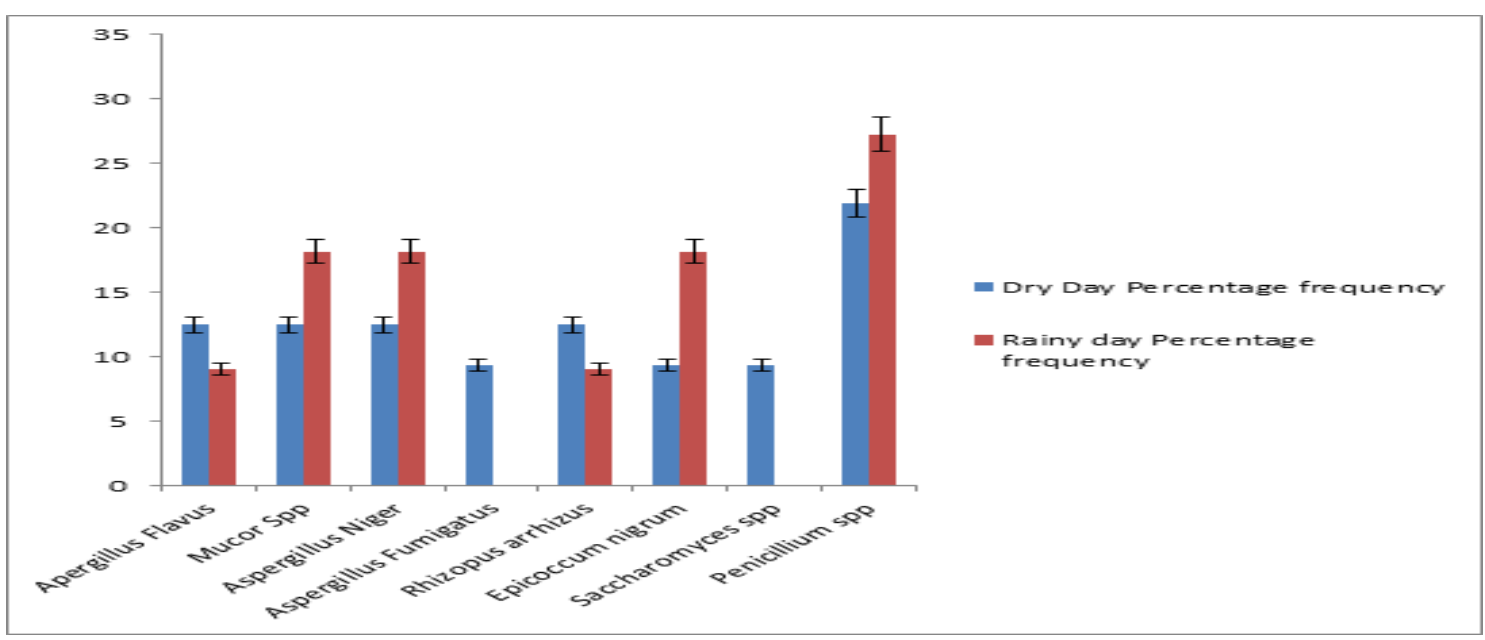

Fig.5 Percentage frequency for heterotrophic bacteria from sample site 2 (RSU poultry farm)

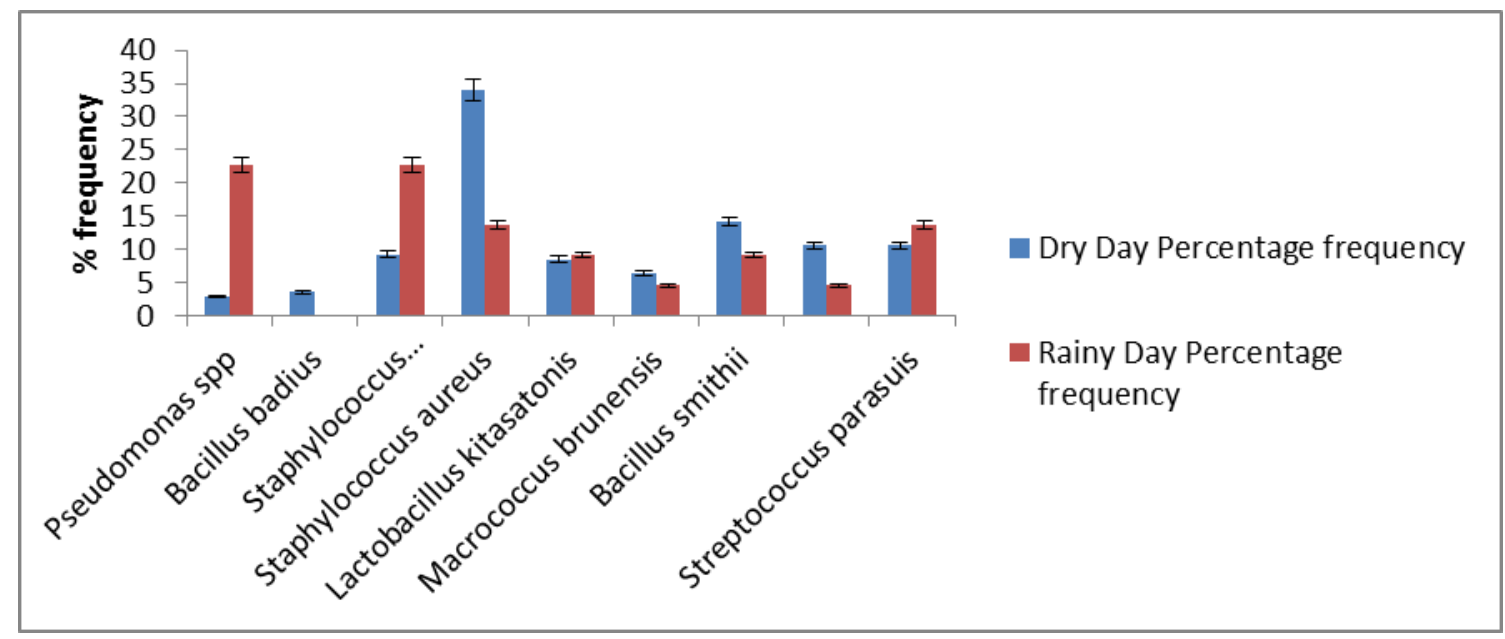


Fig.6 Percentage frequency of enteric bacteria from sample site 2 (RSU poultry farm)

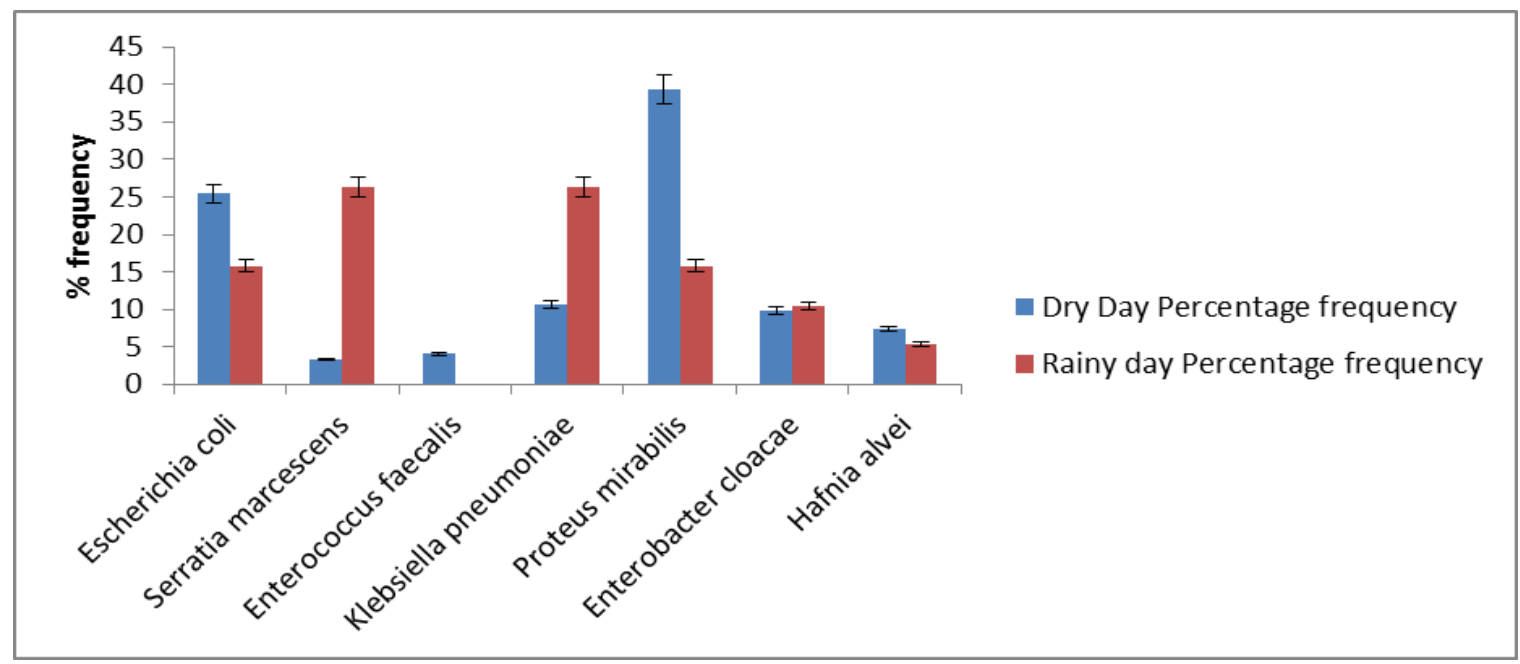

Based on this study, it was concluded that the anthropogenic activities of man, such as the Sawmill and poultry farm give rise to organic dusts and organic dust inhalation results in many acute and chronic diseases of the pulmonary tract especially in immunecompromised individuals. This work revealed the microorganisms associated with organic dusts and discovered some pathogenic bacteria and fungi that can cause serious infections and inflammation of the respiratory tract. The first and fundamental step in the control of organic dust hazards is their recognition, but recognition requires a clear understanding of the nature, origin, mechanism if generation and release of the particles, as well as knowledge on the conditions, of exposure and possible associated side effects.

\section{Recommendation}

It is recommended that exposed workers wear the most practical respirators with the high assigned protection factor (APF).

The poultry farm should be well ventilated so as to reduce dusts.

Health education and periodic medical examination of individuals exposed to organic dust should be practised.

Regular cleaning of poultry and saw-mill environments should be observed.

Proper personal hygiene should be encouraged amongst personnel working in the poultry and saw-mill.

The use of protective gears such nose mask, helmets, and safety boots should be encouraged amongst workers and visitors within the facilities.

Immuno-compromised individuals should avoid exposure to organic dust prone areas and affected individuals should consult a physician for medical check- up.

\section{References}

Achudume, A.C., Oladipo, B.O., (2009). Effects of dust storm in health in the Nigerian environment. Biology and Medicine 1(4): 21-27.

Alexander, M., Tatara, B.S., Antonios, G.M., Dimitrios, P. K., (2016). Factors affecting patient outcome in primary cutaneous aspergillosis. Medicine (Baltimore) Journal; 95(26): e3747.

Amy, L. S., 2014. Respiratory Disorders 3rd edition. Peter E. Ruffner, Publisher.

An, H., Englehardt, J., Fleming, L., Bean, J. 
(1999) Occupational Health and Safety amongst Municipal Solid Waste Workers in Florida; Waste Management Res. 17, pp 369-377.

Avila, R., and Lacey, J. (2014). The role of Penicillium frequetams in suberosis. Respiratory disease in the cork industry. Journal of Clinical Allergy, 4(1), 109-117.

Boutin, P., Torrre, M.., and Moline, J. (2015). Bacterial and fungal atmosphere contamination at refuse composting plants a preliminary study in compost production, quality and use, London, US: Jenkinns Press.

Brendan, R. J., Tom M.C. (2018) Yellow Book. Travelers Health [Center for Disease Control].

Burg, W. R.., and Shotwell, O.L. (2013). Aflatoxin levels airborne dust generated form contamination corn during harvest and at an elevator. Journal of Association of Analytical Chemistry, 67 (1), 309-312.

Chaudemanche, H., Monnet, E., Westeel, V., Pernet, D., Dubiez, A., Perrin, C., (2003). Respiratory status in dairy farmers in France; cross sectional and longitudinal analyses. Journal of Occupational and Environmental Medicine; 60(11): 858863. doi: 10.1136/oem.60.11.858

Cohen, H.I., Maerigan, T.C., Kosek, J.C., and Eldridge, F. (2012) Sequoiosis: a granulomatous pneumonitis associated with redwood sawdust inhalation. American Journal of Medicine, 43 (1): 785-794.

Crook, B., Bardos, P, and Lacey, J. (2015). Domestic waste composting plants as sources of inborne microorganisms. In Aerosols their generation, behavior and application Aerosol society conference, WWD Griffiths (ed.). Aersol society, London, 63-68.

Denning, D.W. (1998) Invasive Aspergillosis. Clinical Infectious Diseases; 26(4):781803.

Donham, K.J. and Thelin, A., (2006). Agricultural medicine: Occupational and Environmental Health for the Health Professions. Ames, Iowa: Blackwell publishing.

Douwess, J., Peter, S., Thorne, Dick Heederick', 2003.Monitoring and Evaluation of Bioaerosol Exposure.

Duchaine C., Meriaux A., Thorne P.S., Cormier, Y. (2000) Assessment of particulates and bioaerosols in eastern Canadian sawmills. American Industrial Hygiene Association Journal, 61, 727-732.

Dutkiewicz, J., Krysinska-Traczyk, E., Prazmo, Z., Sitkowska J. (2001) Exposure to airborne microorganisms in Polish sawmills. Annual Agricultural and Environmental Medicine, 8, 71-80.

Eduard W: Assessment of Mould Spore Exposure and Relations to Symptoms in Wood Trimmers. Agricultural University, Wageningen, The Netherlands 1993.

Envis, N., (2012). Byssinosis. Indian council of medical research, New Delhi; 7(2):1-8

Fernández, Pérez E.R., Swigris J.J, and Forssén A.V., (2013). Identifying an inciting antigen is associated with improved survival in patients with chronic hypersensitivity pneumonitis. American Chest Journal; 144(5):1644-1651. doi: 10.1378/chest.12-2685.

Fink, J.N., Ortega, H.G., Fan, L.L., Franks, T.J., Kreiss, K., (2005). Needs and opportunities for research in hypersensitivity pneumonitis. American Journal of Respiratory and Critical Care Medicine; 171(7):792-8

Garbino Jorge (2004) - Aspergillosis, Orphanet Encyclopedia.

Gian, G.R. and Androula, M. (2017). Hypersensitivity pneumonitis: a complex lung disease. Clinical and molecular allergy; 15: 6.doi: 10.1186/s12948-0170062-7

Girard, M., Cormier Y(.2010) Hypersensitivity pneumonitis. Current Opin Allergy Clinimmunol. 10:99-103.

Hartung, J., Schulz, J. (2011) Occupationl and environmental risks caused by bioaerosols in and from farm animal houses. Agric Eng Int 2011; 13:2 Australian Centre for Agricultural Health and Safety, Organic Farm Dusts,(12) 
Heldal, K.K., Breum, N.O., Nielsen, B.H., Wilkins, K. Experimental Generation of Organic Dust from Compostable Household Waste; Waste Manage. Res. 2001, 19, 98-107.

Ivens, U.I., Breum, N.O., Ebbehoj, N., Nielsen, B.H., Poulsen, O.M., Wurt, Z.H. Exposure-Response Relationship between Gastrointestinal Problems among Waste Collectors and Bioaerosol Exposure; Scand. J. Work Environ. Health 1999, 25, 238-245.

Judson MA. Noninvasive Aspergillus pulmonary disease. SeminRespirCrit Care Med 2004; 25(2):203-219.

Karkhanis, V.S., and Joshi, J.M. (2011). Cement dust exposure related emphysema in construction worker. Journal of Long India, 28(4), 294-296.

Kauffman, C.A (2007) Histoplasmosis: a clinical and laboratory update-clinical microbiology reviews.

Kirkhorn, S.R., Gary, V.F., (2000). Agricultural lung diseases.Environ Health perspect; 108(4): 705-12.

Kozakiewcz, Z., Smith, D. (1994). Physiology of Aspergillus. In: Smith JE, editor. Biotechnology Uandbooks-7; Aspergillus. New York; Plenum Press 23-40.

Krucik, G. (2016). Byssinosis: brown lungs and what you need to know about them. Available at https://www.healthline.com. Accessed on 2nd January, 2018.

Krysińska-Traczyk, E., (2000). Microflora of the farming work environment as an occupational risk factor. Medycynapracy; 51(4):351-5.

Kwon-Chung, K.J., Suguw, J.A (2013) Aspergillus fumigatus - what makes the species a Ubiquitous Human Fungal Pathogen? PLOS Pathog; 9(12):e1003743.

Laakkonen, A. (2008) Occupational exposure to organic dusts and cancer among Finnish workers: special emphasis on the food industry and agriculture.

Laakkonen, A., Kyyronen, P., Kauppinen, T., and Pukkala, K.I. (2015). Occupational exposure to eight organic dusts and respiratory cancer among Finns. Journal of
Occupational and Environmental Medicine, 63 (11), 726-733.

Lacasse, Y., Girard, M., Cormier, Y., (2012). Recent advances in hypersensitivity pneumonitis. American Chest Journal; 142(1):208-217. doi: 10.1378/chest.112479.

Lacasse, Y., Selman, M., Costabel, U., Dalphin, J.C., Ando, M., Morell, F., (2003).Clinical diagnosis of hypersensitivity pneumonitis. American Journal of Respiratory and Critical Care Medicine; 168(8):952-8.

Lacey, J. (2010).Hazards to health from airborne spores in the mushroom industry. In Aerosols; their generation, behavior and application. Aerosol Society Second conference, WD Graffiths (ed) Aerosol Society, London, 89-94.

Lacey, J. (2011). Thermoactinomyces, sacchari sp. no. A thermphilic actinomycetes causing bagassosis. Journal of General Microbiology, 66(2), 327-378.

Lacey, J. (2016).Microorganisms in organic dusts.Available https:///www.books.google.com.ng.Access ed on 2nd January, 2018.

Lacey, J. (2014) Actinomycetes in tools, composts and todders. In actinomycetales: characteristic and practical importance, F.A Skinner and G. Sykes (eds), Soci. Applied Bacteriological Symptoms, 2 (2), 231-251.

Latge J.P (1999). Aspergillus fumigatus and aspergillosisis. Clin Microbial Rev 12; 310-350.

Lee, S.H., Lee, B.J., Jung, do Y., (2004). Clinical manifestations and treatment outcomes of pulmonary Aspergilloma. Korean J Intern Medical; 19(1):38-42.

Lies, L., Leen, J.M., Seys, G.F., (2017). Epidemiology and impact of chronic bronchitis in chronic obstructive pulmonary disease. European Respiratory Journal; 50(2): $1602470 . \quad$ doi: 10.1183/13993003.02470-2016.

Louhlelainen, K (2005): Organic dusts. In: Chemicals at work-Report of the Finnish Institute of Occupational Health for the National Programme on Chemical Safety 
(in Finnish); Pp. 49-53.

Marwan M. and Chadi A. H., (2017).Laboratory Diagnostics for Histoplasmosis. Journal of Clinical Microbiology; 55(6): 1612-1620.

May S., Romberger D.J, Poole J.A. Respiratory Health Effects of Large Animal Farming Environments. J. Toxicol. Environ. Health B.2012; 15:524-541.

Medifocus Guidebook (2011). Chronic bronchitis 11529 Daffodil lane; Medifocus Publications.

Meyer, P., Andersson, M., Persson, C.G., Greiff, L., (2003).Steroid-sensitive indices of airway inflammation in children with seasonal allergic rhinitis. Pediatr Allergy Immunol., 14(1): 60-5.

Minárik L, Mayer M, Votrubová V, Ürgeová N, Dutkiewicz J: Allergic alveolitis due to antigens present in mouldy beech chips description of two cases. Studia Pneumol Phtiseol Cechoslov 1983, 43, 38-45 (in Slovak).

Morgan, J., Wannemuehler, K.A., Marr, K. A, (2005). Incidence of invasive aspergillosis following hematopoietic stem cell and solid organ transplantation: interim results of a prospective multicenter surveillance program. Medical Mycology; 43(1)49-58.

Murlidhar, V. and Kanhere V., (1995). Byssinosis in a Bombay textile mill. The National medical journal of India; 8(5):204-207

Oldenburg, M., Latza, U., Baur, X. L., (2007).Exposure-response relationship between endotoxin exposure and lung function impairment in cotton textile workers, Int Arch Occup Environ Health; 80: (388-95).

Olga V.P., Su-lin L.L., (2011) Swedish University of Agricultural Sciences, Uppsala, Sweden Published online: August 2011.

Omland, O. (2002) Exposure and respiratory health in farming in temperate zones - a review of the literature. Ann Agric Environ Med; 20029119-136.

Omland, O. (2016). Exposure and respiratory health in farming in temperate zones: a review of the literature. Ann Agric Environ Med. 9(2), 119-36.

Phillippa, J.P., and Peter, N.B., (2001). Oral mucolytic drugs for exacerbations of chronic obstructive pulmonary disease: systematic review. British Medical Journal; 322(7297): 1271.

Pietro, M. (2017). Allergic and asthmatic bronchitis. Causes and treatments. Available at https://www.medical newstoday.com. Accessed on $2^{\text {nd }}$ Februrary, 2018

Plain, R.L., Lawrence, J., Swine production. Vet Clin North Am Food AnimPract. 2003; 19:319-337.

Poulsen, O.M., Breum, N.O.,Ebbehoj, N., Hansen, A.M.,Ivens, U.I Nielsen, E.M.(1995,) Collection of Domestic Waste. Review of Occupational Health Problems and Their Possible Causes; Sci. Total Environ., 170, 1-19.

Rask Andersen A. (1988). Pulmonary Reactions to Inhalation of Mould Dust in Farmers With Special Reference to Fever and Alveolitis [Doctoral thesis\ Uppsala University[ Sweden].

Rask-Andersen A., Land C.J., Enlund K., Lundin A., Inhalation fever and respiratory symptoms in the trimming department of Swedish sawmills. American journal and industrial medicine 1994, 25, 65-67.

Rapini, R. P., Bolognia, J. L; Jorizzo J. L. (2007). Dermatology: 2-Volume Set. St. Louis: Mosby: ISBN 1-4160-2999-0.

Rees, P.J. and Dudley, F., (1998).Oxygen therapy in chronic lung disease. British medical journal; 317(7162): 871-874.

Rementeria A, Lopez-Molina N, Ludwig A., (2005). Genes and molecules involved in Aspergillus fumigatus virulence. Rev IberoamMicol; 22(1):1-23.

Ryan S. D. and Anthony D., (2017). Hypersensitivity pneumonitis: an overlooked cause of cough and dyspnea. Journal of Community Hospital Internal Medicine Perspective; 7(2): 95-99. doi: 10.1080/20009666.2017.1320202

Rylander R, Jacobs RR, (1994): Organic dusts: exposure, effects and prevention. Chicago, 
IL: Lewis Publishing Inc.

Ragnar, R., (2002). Endotoxin in the environment - exposure and effects. Journal of Endotoxin Research; 8(4):241252

Rylander, R. (2004): Organic dusts and diseases-A continuous research challenge. American Journal. Industrial Medicine 46:323-326.

Rylander R, Schilling RSF. Encyclopedia of Occupational Health and Safety, 1998 Eduard W, Halstensen AS. Quantitative exposure assessment of organic dust. SJWEH Suppl. 2009;(7):30-35.

Sautor, M., Mary P, Chihub, N.E and Hornex, Z.P, (2013).The effects of temperature, water activity and $\mathrm{PH}$ on the growth of Acromonas hydrophila and on its subsequent survival in microcosm water. Journal of Applied Microbiology, 95(4), 807-813.

Schenker M. (2000) Exposures and Health Effects from Inorganic Agricultural Dusts Environmental Health Perspectives Vol 108(4):661-664.

Schubert, M.S., (2004). Allergic fungal sinusitis: pathogenesis and management strategies. Drugs; 64(4):363-74.

Selman, M., Pardo, A., King, T.J. (2012). Hypersensitivity pneumonitis: insights in diagnosis and pathobiology. American Journal of Respiratory and Critical Care Medicine; 186(4):314-24. doi: 10.1164/rccm.201203-0513CI
Silberberg, P. (2007). "Radiology Teaching Files: Case 224856 (Histoplasmosis). "Retrieved 2007-07-27.

Simpson, J.C., Niven, R.M., Pickering, C.A.(1998) Prevalence and predictors of work related respiratory symptoms in workers exposed to organic dusts, Occup Environ Med, 55 (668-72)

The National Institute for Occupational Safety nd Health (NIOSH) (2017) Histoplasmosis: protating workers at risk. Available at https:www.cdc.gov.

Wan, C. T., Jean, B., Paul, H., Kenneth, R. C., (2013). Bronchodilator Responsiveness and Reported Respiratory Symptoms in an Adult Population. PLos One; 8(3): 58932. doi: 10.1371/journal.pone.0058932

Wang, X.R., Eisen, E.A., Zhang, H.X., (2003). Respiratory symptoms and cotton dust exposure: results of a 15 year follow up observation, Occup Environ Med; 60: 93541.

Yamamoto, K., Abe, M., Inoue, Y., and Yokoyama, A., et al., (2015) Development of infection with Aspergillus flavus in a woman being located for allergic pulmonary aspergillosis caused by Aspergillus fumigatus, Nippon. Kyobu SlikkenGakkaiZasshi, 33(1), 1099-1101.

Zmeili, O.S. and Soubani, A.O., (2007). Pulmonary aspergillosis: a clinical update. $Q \quad J \quad$ Med; $\quad 100: 317-334$. doi:10.1093/qjmed/hcm035

\section{How to cite this article:}

Baranu, B.S. and Edmund, E. 2019. Microorganisms Isolated from Sawmill and Poultry Farm and their Long Term Health Effects in Human Health. Int.J.Curr.Microbiol.App.Sci. 8(03): 809-821. doi: https://doi.org/10.20546/ijcmas.2019.803.098 